\title{
Selectivity of phytosanitary products used in organic farming on adult of Cryptolaemus montrouzieri (Coleoptera, Coccinellidae) under laboratory conditions
}

\author{
Seletividade de produtos fitossanitários, usados no sistema de \\ produção orgânica, sobre adultos de Cryptolaemus montrouzieri \\ (Coleoptera, Coccinellidae), em laboratório
}

\author{
Caio Fábio Stoffel Efrom ${ }^{1 *}$; Luiza Rodrigues Redaelli²; Rafael Narciso Meirelles $^{3}$; \\ Cláudia Bernardes Ourique ${ }^{4}$
}

\begin{abstract}
The association of pesticides with biological control is possible only if they provide some selectivity to natural enemies. In the organic production system the effect of insecticides on beneficial insects has not been extensively studied. Thus, this study aimed to evaluate in laboratory conditions the effect of pesticides used in this system on the adults of the predator Cryptolaemus montrouzieri Mulsant (Coleoptera, Coccinellidae). We used four treatments, which corresponded to four multiple values $(0.25 \mathrm{x}, 0.5 \mathrm{x}, 2 \mathrm{x}$ and $1 \mathrm{x})$ of the concentration recommended by manufacturers of the following products: Rotenat $\mathrm{CE}^{\circledR}$, Pironat ${ }^{\circledR}$, Biopirol $7 \mathrm{M}^{\circledR}$, Organic $\mathrm{Neem}^{\circledR}$, Natuneem ${ }^{\circledR}$ and lime sulfur, which were tested in C. montrouzieri by topical application and residual exposure. None of the products, at any concentrations tested, had a significant effect on the survival of adults of $C$. montrouzieri, what did not differ from the distilled water control, showing that the products tested are selective to the adults of this species. However, other forms of exposure and evaluation methods must be studied.
\end{abstract}

Key words: Predator, beneficial insect, rotenone, lime sulfur, neem, pyroligneous extract

\section{Resumo}

A associação do controle biológico com produtos fitossanitários só é possível se estes apresentarem alguma seletividade aos inimigos naturais. No sistema de produção orgânica, o efeito de inseticidas sobre insetos benéficos não tem sido extensivamente estudado. Assim, este trabalho objetivou avaliar em laboratório o efeito de produtos fitossanitários utilizados neste sistema, sobre adultos do predador Cryptolaemus montrouzieri Mulsant (Coleoptera, Coccinellidae). Foram utilizados quatro tratamentos, os quais corresponderam quatro múltiplos $(0,25 \mathrm{x}, 0,5 \mathrm{x}, 1 \mathrm{x}$ e $2 \mathrm{x})$ da concentração recomendada pelos fabricantes dos seguintes produtos comerciais: Rotenat $\mathrm{CE}^{\circledR}$, Pironat ${ }^{\circledR}$, Biopirol $7 \mathrm{M}^{\circledR}$, Organic neem ${ }^{\circledR}$, Natuneem ${ }^{\circledR} \mathrm{e}$ calda sulfocálcica, que foram testados sobre C. montrouzieri por aplicação tópica e exposição a resíduos. Nenhum dos produtos, em qualquer das concentrações testadas, apresentou efeito significativo sobre a sobrevivência de adultos de C. montrouzieri, não diferindo da testemunha água destilada, demonstrando

\footnotetext{
1 Pesquisador, Dept ${ }^{\circ}$ de Fitossanidade, Faculdade de Agronomia, Universidade Federal do Rio Grande do Sul, UFRGS, Porto Alegre, RS. E-mail: caioefrom@hotmail.com

2 Prof $^{a}$ associada, Dept ${ }^{\mathrm{o}}$ de Fitossanidade, Faculdade de Agronomia, UFRGS, Porto Alegre, RS. E-mail: luredael@ufrgs.br

3 Discente de doutorado, Dept ${ }^{\circ}$ de Fitossanidade, Faculdade de Agronomia, UFRGS, Porto Alegre, RS. E-mail: rafael.meirelles@ ufrgs.br

4 Discente de graduação, Dept ${ }^{\circ}$ de Fitossanidade, Faculdade de Agronomia, UFRGS, Porto Alegre, RS. E-mail: claudiaourique@ hotmail.com

* Autor para correspondência
} 
que os produtos testados são seletivos aos adultos dessa espécie.

Palavras-chave: Predador, inseto benéfico, rotenona, calda sulfocálcica, nim, extrato pirolenhoso

\section{Introduction}

In organic production systems, although it is recognized the increase of the family income and the reduction in the amount of negative impacts to the environment (MAGANO et al., 2003), there is still a lack of appropriate technologies for the management of pests and diseases. Phytosanitary treatments usually applied to pests control have a side effects on beneficial insects such as pollinators and natural enemies, mainly due to the most common form of contamination, which is the contact with residual products. Generally, these insects have a larger contact surface in relation to their body volume, are quite mobile, depend on their hosts and have enzyme systems that are less complex (CROFT, 1990).

Thus, the use of phytosanitary products should be made only if these products present some selectivity for beneficial fauna, such as natural enemies (RIPPER; GREENSLADE; HARTLEY, 1951; CROFT, 1990; RIGITANO; CARVALHO, 2001). However, very little has been done in order to study the effects of such chemicals on beneficial organisms (TEDESCHI; ALMA; TAVELLA, 2001; ULRICHS; MEWIS; SCHNITZLER, 2001; ROCHA, 2008).

Cryptolaemus montrouzieri Mulsant (Coleoptera, Coccinellidae), a native species from Australia, has been used commercially in many programs of classical biological control of several species of scale insects and aphids in the world (SANCHES; SILVA; CARVALHO, 2000). According to Babu and Azam (1987a), this ladybug is a generalist predator that feeds on a wide range of insect species. It is considered the most important agent to control the citrus mealybug Planoccocus citri (Risso) (Hemiptera, Pseudococcidae), particularly in citrus (BARTLETT; LLOYD, 1958). In Brazil, in 1973, there was the first introduction of C. montrouzieri to control Dysmicoccus sp. (Hemiptera: Pseudococcidae) in pineapple, but with no successes in the establishment in the new habitat (BERTI FILHO; MENEZES; MORAES, 1973). In 1998, it was introduced again, with the goal of establishing this predator in commercial citrus orchards and other tropical fruit to control scale insects and aphids, with success particularly in control of Planococcus citri (Hemiptera: Pseudococcidae) (NARDO et al., 1999).

There are few studies related to the effect of phytosanitary products on C. montrouzieri. However, in these studies it was clear the tolerance of different species to distinct products (BELLOWS et al. 1985; BABU; AZAM, 1987b; SIMMONDS et al., 2000; SMITH; KRISCHIK, 2000; ROSSINI et al., 2003; BOYERO et al., 2005; ROCHA, 2008). In Brazil, the study of Rocha (2008) is a pioneer in evaluating the selectivity of pesticides used in coffee culture on $C$. montrouzieri.

Considering that the effect of insecticides on beneficial insects in organic production system has not been extensively studied the aim of this work was to evaluate the effects on adult $C$. montrouzieri of topical and residual exposure of six commercial formulations allowed in organic farming under laboratory conditions, classifying them according to the criteria of the IOBC (International Organization of Biological Control) (HASSAN et al., 1992).

\section{Material and Methods}

The bioassays to assess the effects of the products on Cryptolaemus montrouzieri were conducted in laboratory $\left(25 \pm 2^{\circ}\right.$ C, R.H. $70 \pm$ $10 \%$ and photoperiod of 12 hours). The adults of C. montrouzieri were purchased from the company Gravena Manecol Ltda. The experiments were performed two hours after the insects arrival. 


\section{Topical exposure}

The adults were treated individually with a dose of $0.5 \mathrm{ml}$ of pesticide solution (Table 1) applied topically on the dorsal surface of the thorax, using $1 \mathrm{ml}$ Microsyringe, coupled with a manual micro-applicator (Burkard Manufacturing Co. Ltd.).

Table 1. Products and concentrations evaluated on Cryptolaemus montrouzieri (Coleoptera, Coccinellidae) adults mortality in the laboratory.

\begin{tabular}{|c|c|c|c|c|}
\hline Product & $\begin{array}{l}\text { Trade } \\
\text { name }\end{array}$ & $\begin{array}{c}\text { Product } \\
\text { Information }\end{array}$ & $\begin{array}{l}\text { Concentrations used } \\
\text { (ml } 100 \mathrm{l}^{-1} \text { of water)* }\end{array}$ & Manufacturer \\
\hline Neem Oil & Organic neem $^{\circledR}$ & $\begin{array}{l}80 \% \text { neem oil } \\
1500 \mathrm{ppm}\end{array}$ & $125,250, \mathbf{5 0 0}, 1000$ & Dalquim \\
\hline Neem Oil & Natuneem $^{\circledR}$ & $\begin{array}{c}\text { azadirachtin } \\
\text { extract of Derris }\end{array}$ & $125,250, \mathbf{5 0 0}, 1000$ & Natural Rural \\
\hline Rotenone & Rotenat ${ }^{\circledR}$ & $\begin{array}{c}\text { spp. with } 5 \% \\
\text { rotenone }\end{array}$ & $150,300, \mathbf{6 0 0}, 1200$ & Natural Rural \\
\hline Lime sulfur & --- & $20 \% \mathrm{~S}+9 \% \mathrm{Ca}$ & $1250,2500, \mathbf{5 0 0 0}, 10000$ & Sul Fertilizantes \\
\hline Pyroligneous extract & Pironat $\mathbb{R}$ & - & $62,5,125, \mathbf{2 5 0}, 500$ & Natural Rural \\
\hline Pyroligneous extract & Biopirol 7M ${ }^{\circledR}$ & - & $50,100, \mathbf{2 0 0}, 400$ & Biocarbo \\
\hline Carbaryl & Sevin $480 \mathrm{SC}^{\circledR}$ & 480 ppm a.i. & 225 & Bayer Cropscien \\
\hline
\end{tabular}

* The concentration recommended by the manufacturers in bold.

The pattern of control used was the product Sevin $480 \mathrm{SC}^{\circledR}\left(225 \mathrm{ml} 100 \mathrm{l}^{-1}\right.$ water $)$, as used by Smith and Krischik (2000).

After application, the insects were placed in plastic pots $(550 \mathrm{ml})$, covered with voile fabric to allow gas exchange, and kept in an environmental room, fed with an aqueous solution of honey at $15 \%$ through a strip of Spontex Resist ${ }^{\circledR}$ inserted into a glass tube of $5 \mathrm{ml}$, fixed with parafilm, and a solid diet consisting of sucrose, brewer's yeast, wheat germ and corn gluten, in the ratio $3: 1: 1: 1$, respectively. The bioassay was conducted in a randomized design that took into account products and concentrations (treatments), using three replicates per treatment. Each experimental unit consisted of ten adults of $C$. montrouzieri.

\section{Residual exposure}

The bioassay of residual effect used a methodology based on Jacas and Viñuela (1994). Fifteen adult of C. montrouzieri in each concentration/treatment, with three replicates, were placed in cages whose detachable parts, upper and lower, were square plates of glass $(12 \mathrm{~cm} \times 12 \mathrm{~cm})$, and the sidewall was an acrylic cylinder (4 cm high $\mathrm{x} 9 \mathrm{~cm}$ diameter) with seven holes to allow gas exchange side (connected to an air pump to force the flow) and food (the same of the previous experiment) and water were provided. The treatments consisted on four concentrations of 
commercial formulations of products (Table $1)$. The products were applied using hand sprayers $(500 \mathrm{ml})$ on the internal faces of the glass plates in a volume of $1.5 \pm 0.25 \mathrm{mg} / \mathrm{cm}$ ${ }^{2}$, measured on an electronic scale (Indústria e Comércio Eletro Eletrônica Gehaka Ltda.). The cages were assembled again, after the plates were dried out at room temperature, and then the insects were introduced. The experiment was kept in an environmental room.

\section{Evaluation of experiments of contact and residual in Cryptolaemus mountrozieri}

In both experiments the action of the products was evaluated by the number of individuals surviving $15 \mathrm{~min}, 30 \mathrm{~min}, 1,4,12,24,48,72$ and 96 hours after treatment with insecticides. The survival values were corrected by Abbott's formula (ABBOTT, 1925) and the variation in the number of surviving insects per treatment was transformed to arcsine of $\sqrt{ }(\mathrm{x} / 100)$ and subjected to repeated measures analysis of variance, using SPSS 15 software, comparing the means by Tukey test at 5\% probability, when in the presence of significance. The results were classified according to criteria of the IOBC (International Organization for Biological Control) for laboratory tests on beneficial organisms (HASSAN et al., 1992), and classified into: 1) harmless (mortality < $30 \%)$, 2) slightly harmful ( $>30 \%$ and $<79 \%$ ), 3 ) moderately harmful ( $>80 \%$ and $<99 \%$ ), and 4) harmful (>99\%).

\section{Results and Discussion}

None of the products, at any tested concentrations, had a significant effect on the survival of adult $C$. montrouzieri by either topical application (Table 2) and residual exposure (Table 3), except for the control Carbaryl $\left(225 \mathrm{ml} 100 \mathrm{l}^{-1}\right)$, where mortality was only observed 24 hours after treatment, without significant differences between 24, 48, 72 and 96 hours $(\mathrm{P}=0.857)$. Thus, only observations at 24 and 96 hours are presented in Tables 2 and 3 . The mortality values always remained below $4 \%$ during all observations, for all treatments and concentrations, and in the two application methods tested.

The absence of significant differences among the experiment repetitions indicated that the commercial lots of $C$. montrouzieri used in the experiment responded similarly to treatment (topical, $\mathrm{P}=0.863$; residual exposure, $\mathrm{P}=0.894)$. With respect to products based on neem oil, the results are similar to those reported by Smith and Krischik (2000) and Rossini et al. (2003).

In both studies the authors found no significant differences on mortality of $C$. montrouzieri adults when they were sprayed with a commercial formulation of neem. In other species of coccinellid, Coccinella septempunctata L., Banken and Stark (1998) did not observed adults mortality when sprayed with commercial products containing azadirachtin. The authors, however, found a reduction in oviposition and a delay on the larval developmental, factors that were not evaluated in this study.

Testing neem oil on larvae of Cycloneda sanguinea (L.), Silva and Martinez (2004) found that the product caused larval mortality $\left(60 \%\right.$ mean survival at $\left.5 \mathrm{ml} \mathrm{l}^{-1}\right)$. However, the adults emerged from treated larvae showed no changes in sex ratio, fecundity, fertility and longevity. 
Table 2. Average number of live insects ( \pm SD) and corrected mortality (Mc in \%) of Cryptolaemus montrouzieri (Coleoptera, Coccinellidae) adults 24 and 96 hours after treatment via topical application $(0.5$ $\mu \mathrm{l} /$ insect $)\left(25 \pm 2{ }^{\circ} \mathrm{C}, 70 \pm 10 \% \mathrm{RH}\right.$, photoperiod: 12 hours $)$.

\begin{tabular}{|c|c|c|c|c|c|c|}
\hline \multicolumn{2}{|c|}{ Treatments } & \multirow[t]{3}{*}{ Conc. ${ }^{1}$} & \multicolumn{4}{|c|}{ Time (hours) } \\
\hline & & & \multirow[t]{2}{*}{24} & \multirow[t]{2}{*}{ Mc } & \multirow[t]{2}{*}{96} & \multirow[t]{2}{*}{ Mc } \\
\hline Product & trade name & & & & & \\
\hline \multirow[t]{4}{*}{ Neem Oil } & Organic neem ${ }^{\circledR}$ & 125 & $10.0 \pm 0.00 \mathrm{Aa} 2$ & 0 & $10.0 \pm 0.00 \mathrm{Aa}$ & 0 \\
\hline & & 250 & $10.0 \pm 0.00 \mathrm{Aa}$ & 0 & $10.0 \pm 0.00 \mathrm{Aa}$ & 0 \\
\hline & & 500 & $10.0 \pm 0.00 \mathrm{Aa}$ & 0 & $10.0 \pm 0.00 \mathrm{Aa}$ & 0 \\
\hline & & 1000 & $10.0 \pm 0.00 \mathrm{Aa}$ & 0 & $10.0 \pm 0.00 \mathrm{Aa}$ & 0 \\
\hline \multirow[t]{4}{*}{ Neem Oil } & Natuneem $^{\circledR}$ & 125 & $10.0 \pm 0.00 \mathrm{Aa}$ & 0 & $10.0 \pm 0.00 \mathrm{Aa}$ & 0 \\
\hline & & 250 & $10.0 \pm 0.00 \mathrm{Aa}$ & 0 & $10.0 \pm 0.00 \mathrm{Aa}$ & 0 \\
\hline & & 500 & $10.0 \pm 0.00 \mathrm{Aa}$ & 0 & $10.0 \pm 0.00 \mathrm{Aa}$ & 0 \\
\hline & & 1000 & $9.7 \pm 0.57 \quad \mathrm{Aa}$ & 3.33 & $9.7 \pm 0.57 \quad \mathrm{Aa}$ & 3.33 \\
\hline \multirow[t]{4}{*}{ Rotenone } & Rotenat $^{\circledR}$ & 150 & $10.0 \pm 0.00 \mathrm{Aa}$ & 0 & $10.0 \pm 0.00 \mathrm{Aa}$ & 0 \\
\hline & & 300 & $10.0 \pm 0.00 \mathrm{Aa}$ & 0 & $10.0 \pm 0.00 \mathrm{Aa}$ & 0 \\
\hline & & 600 & $10.0 \pm 0.00 \mathrm{Aa}$ & 0 & $10.0 \pm 0.00 \mathrm{Aa}$ & 0 \\
\hline & & 1200 & $9.7 \pm 0.57 \quad \mathrm{Aa}$ & 3.33 & $9.7 \pm 0.57 \quad \mathrm{Aa}$ & 3.33 \\
\hline \multirow[t]{4}{*}{ Lime sulfur } & --- & 1250 & $10.0 \pm 0.00 \mathrm{Aa}$ & 0 & $10.0 \pm 0.00 \mathrm{Aa}$ & 0 \\
\hline & & 2500 & $10.0 \pm 0.00 \mathrm{Aa}$ & 0 & $10.0 \pm 0.00 \mathrm{Aa}$ & 0 \\
\hline & & 5000 & $10.0 \pm 0.00 \mathrm{Aa}$ & 0 & $10.0 \pm 0.00 \mathrm{Aa}$ & 0 \\
\hline & & 10000 & $10.0 \pm 0.00 \mathrm{Aa}$ & 0 & $10.0 \pm 0.00 \mathrm{Aa}$ & 0 \\
\hline \multirow{4}{*}{$\begin{array}{l}\text { Pyroligneous } \\
\text { extract }\end{array}$} & Pironat $\mathbb{R}$ & 62,5 & $10.0 \pm 0.00 \mathrm{Aa}$ & 0 & $10.0 \pm 0.00 \mathrm{Aa}$ & 0 \\
\hline & & 125 & $10.0 \pm 0.00 \mathrm{Aa}$ & 0 & $10.0 \pm 0.00 \mathrm{Aa}$ & 0 \\
\hline & & 250 & $10.0 \pm 0.00 \mathrm{Aa}$ & 0 & $10.0 \pm 0.00 \mathrm{Aa}$ & 0 \\
\hline & & 500 & $10.0 \pm 0.00 \mathrm{Aa}$ & 0 & $10.0 \pm 0.00 \mathrm{Aa}$ & 0 \\
\hline \multirow{4}{*}{$\begin{array}{l}\text { Pyroligneous } \\
\text { extract }\end{array}$} & Biopirol 7M ${ }^{\circledR}$ & 50 & $10.0 \pm 0.00 \mathrm{Aa}$ & 0 & $10.0 \pm 0.00 \mathrm{Aa}$ & 0 \\
\hline & & 100 & $10.0 \pm 0.00 \mathrm{Aa}$ & 0 & $10.0 \pm 0.00 \mathrm{Aa}$ & 0 \\
\hline & & 200 & $10.0 \pm 0.00 \mathrm{Aa}$ & 0 & $10.0 \pm 0.00 \mathrm{Aa}$ & 0 \\
\hline & & 400 & $9.7 \pm 0.57 \quad \mathrm{Aa}$ & 3.33 & $9.7 \pm 0.57 \quad \mathrm{Aa}$ & 3.33 \\
\hline Carbaryl & Sevin $480 \mathrm{SC}^{\circledR}$ & 225 & $2.0 \pm 1.00 \quad \mathrm{Ab}$ & 90 & $0 \pm 0.00$ & 100 \\
\hline Control & - & - & $20 \pm 0.00 \quad \mathrm{Aa}$ & - & $20 \pm 0.00$ & - \\
\hline
\end{tabular}

1 Conc. = Concentration. $\mathrm{ml}$ of commercial product per 1001 of water. The concentration recommended by the manufacturers in bold

2 Averages followed by different uppercase letters in rows and lowercase letters in columns differ significantly by Tukey's test $(\mathrm{P}<0.05)$. 
Table 3. Average number of live insects ( \pm SD) and corrected mortality (Mc in \%) of Cryptolaemus montrouzieri (Coleoptera, Coccinellidae) adults, 24 and 96 hours after treatment via residual exposure (25 $\pm 2{ }^{\circ} \mathrm{C}, 70 \pm 10 \% \mathrm{RH}$, photoperiod: 12 hours).

\begin{tabular}{|c|c|c|c|c|c|c|}
\hline \multicolumn{2}{|c|}{ Treatments } & \multirow[t]{3}{*}{ Conc. ${ }^{1}$} & \multicolumn{4}{|c|}{ Time (hours) } \\
\hline & & & 24 & Мc & 96 & Mc \\
\hline Product & Trade name & & & & & \\
\hline \multirow[t]{4}{*}{ Neem Oil } & Organic neem $^{\circledR}$ & 125 & $10.0 \pm 0.00 \mathrm{Aa} 2$ & 0 & $10.0 \pm 0.00 \mathrm{Aa}$ & 0 \\
\hline & & 250 & $10.0 \pm 0.00 \mathrm{Aa}$ & 0 & $10.0 \pm 0.00 \mathrm{Aa}$ & 0 \\
\hline & & 500 & $10.0 \pm 0.00 \mathrm{Aa}$ & 0 & $10.0 \pm 0.00 \mathrm{Aa}$ & 0 \\
\hline & & 1000 & $10.0 \pm 0.00 \mathrm{Aa}$ & 0 & $10.0 \pm 0.00 \mathrm{Aa}$ & 0 \\
\hline \multirow[t]{4}{*}{ Neem Oil } & Natuneem ${ }^{\circledR}$ & 125 & $10.0 \pm 0.00 \mathrm{Aa}$ & 0 & $10.0 \pm 0.00 \mathrm{Aa}$ & 0 \\
\hline & & 250 & $10.0 \pm 0.00 \mathrm{Aa}$ & 0 & $10.0 \pm 0.00 \mathrm{Aa}$ & 0 \\
\hline & & 500 & $10.0 \pm 0.00 \mathrm{Aa}$ & 0 & $10.0 \pm 0.00 \mathrm{Aa}$ & 0 \\
\hline & & 1000 & $10.0 \pm 0.00 \mathrm{Aa}$ & 0 & $10.0 \pm 0.00 \mathrm{Aa}$ & 0 \\
\hline \multirow[t]{4}{*}{ Rotenone } & Rotenat $^{\circledR}$ & 150 & $10.0 \pm 0.00 \mathrm{Aa}$ & 0 & $10.0 \pm 0.00 \mathrm{Aa}$ & 0 \\
\hline & & 300 & $10.0 \pm 0.00 \mathrm{Aa}$ & 0 & $10.0 \pm 0.00 \mathrm{Aa}$ & 0 \\
\hline & & 600 & $10.0 \pm 0.00 \mathrm{Aa}$ & 0 & $10.0 \pm 0.00 \mathrm{Aa}$ & 0 \\
\hline & & 1200 & $9.7 \pm 0.57 \quad \mathrm{Aa}$ & 3.33 & $9.7 \pm 0.57 \quad \mathrm{Aa}$ & 3.33 \\
\hline \multirow[t]{4}{*}{ Lime sulfur } & --- & 1250 & $10.0 \pm 0.00 \mathrm{Aa}$ & 0 & $10.0 \pm 0.00 \mathrm{Aa}$ & 0 \\
\hline & & 2500 & $10.0 \pm 0.00 \mathrm{Aa}$ & 0 & $10.0 \pm 0.00 \mathrm{Aa}$ & 0 \\
\hline & & 5000 & $10.0 \pm 0.00 \mathrm{Aa}$ & 0 & $10.0 \pm 0.00 \mathrm{Aa}$ & 0 \\
\hline & & 10000 & $10.0 \pm 0.00 \mathrm{Aa}$ & 0 & $9.7 \pm 0.57 \quad \mathrm{Aa}$ & 3.33 \\
\hline \multirow{4}{*}{$\begin{array}{l}\text { Pyroligneous } \\
\text { extract }\end{array}$} & Pironat $^{\circledR}$ & 62,5 & $10.0 \pm 0.00 \mathrm{Aa}$ & 0 & $10.0 \pm 0.00 \mathrm{Aa}$ & 0 \\
\hline & & 125 & $10.0 \pm 0.00 \mathrm{Aa}$ & 0 & $10.0 \pm 0.00 \mathrm{Aa}$ & 0 \\
\hline & & 250 & $10.0 \pm 0.00 \mathrm{Aa}$ & 0 & $10.0 \pm 0.00 \mathrm{Aa}$ & 0 \\
\hline & & 500 & $10.0 \pm 0.00 \mathrm{Aa}$ & 0 & $10.0 \pm 0.00 \mathrm{Aa}$ & 0 \\
\hline \multirow{4}{*}{$\begin{array}{l}\text { Pyroligneous } \\
\text { extract }\end{array}$} & Biopirol 7 $\mathrm{M}^{\circledR}$ & 50 & $10.0 \pm 0.00 \mathrm{Aa}$ & 0 & $10.0 \pm 0.00 \mathrm{Aa}$ & 0 \\
\hline & & 100 & $10.0 \pm 0.00 \mathrm{Aa}$ & 0 & $10.0 \pm 0.00 \mathrm{Aa}$ & 0 \\
\hline & & 200 & $10.0 \pm 0.00 \mathrm{Aa}$ & 0 & $10.0 \pm 0.00 \mathrm{Aa}$ & 0 \\
\hline & & 400 & $10.0 \pm 0.00 \mathrm{Aa}$ & 0 & $10.0 \pm 0.00 \mathrm{Aa}$ & 0 \\
\hline Carbaryl & Sevin $480 \mathrm{SC}^{\circledR}$ & 225 & $0.0 \pm 0.00 \mathrm{Ab}$ & 100 & $0 \pm 0.00 \quad \mathrm{Ab}$ & 100 \\
\hline Control & - & - & $20 \pm 0.00 \quad \mathrm{Aa}$ & - & $20 \pm 0.00 \quad \mathrm{Aa}$ & - \\
\hline
\end{tabular}

${ }^{1}$ Conc. $=$ Concentration. $\mathrm{ml}$ of commercial product per 1001 of water.

2 Averages followed by different uppercase letters in rows and lowercase letters in columns differ significantly by Tukey's test $(\mathrm{P}<0.05)$. 
Neem-based products action on natural enemies is considered highly variable (ISMAN, 2006). Despite that no mortality has been recorded in this study, it must be taken into account the effects that this product may have on the insects' behavior. Simmonds et al. (2000) found that the searching behavior of larvae and adult $C$. montrouzieri on $P$. citri was affected after application of neem seed extract and a commercial formulation of azadirachtin $\left(\right.$ Azatin $^{\circledR}$ ), with the predator remaining less time in the treated leaves and decreasing the rate of encounters with the prey.

Regarding pyroligneous extract, the results are similar to those of Busoli, Bissoli and Pereira (2003) who found no significant mortality of larvae of Hippodamia convergens GuérinMeneville (Coleoptera: Coccinellidae) using four concentrations ( 0.5 to $2.5 \%)$ of pyroligneous extract (Biopirol $7 \mathrm{M}^{\circledR}$ ), which led the authors to consider the product selective to the species.

In this paper toxicity of rotenone on $C$. montrouzieri was not observed. However and Aguiar-Menezes (2005) argues that this extract is toxic to fish, ladybugs and mites.Although other studies have described toxic effects of lime sulfur on predators such as Iphiseiodes zuluagai (Denmark and Muma) (Acari: Phytoseiidae) (AMARAL; VENZON; PALLINI, 2003), this effect was not found for $C$. montrouzieri adult. However, Venzon et al. (2006) studding products selectivity to spider mites, warn that, before the use of lime sulfur, it is necessary to assess the possible adverse effects on beneficial organisms present in the agroecosystem.

The insecticide carbaryl (Sevin ${ }^{\circledR} 480 \mathrm{SC}-225 \mathrm{ml}$ $100 \mathrm{l}^{-1}$ ) used as a control, in the topical application, resulted in $100 \%$ of insect mortality, only 48 hours after application. Its application through residual exposure, caused a fourfold faster mortality, since in this case $100 \%$ of the insects dead within the first 12 hours. This insecticide is recommended to control coleopteran pests, and it has been used as reference in tests on C. montrouzieri (SMITH; KRISCHIK,
2000).

Classifying the products tested in this experiment, according to IOBC criteria (BAKKER et al., 1992; HASSAN et al., 1992), all can be considered harmless in relation to mortality by contact our residual action on $C$. montrouzieri adults, since the mortality was lower than $30 \%$ (Tables 2 and 3 ), being, therefore, selective. However, other side effects the insecticides to $C$. montrouzieri, such as ingestion of contaminated prey, changes in predator searching behavior, as well as sublethal effects, mainly on larvae, must be studies.

\section{Conclusions}

None of the products had a significant effect on the mortality of $C$. montrouzieri adults either by topical application or residual exposure.

According to IOBC criteria the tested products can be considered harmless by contact and residual action to $C$. montrouzieri adults.

\section{Acknowledgments}

To National Council for Scientific and Technological Development (CNPq) for scholarships granted to authors.

\section{References}

ABBOTT, W. S. A method of computing the efectiveness of an insecticide. Journal of Economic Entomology, Lanham, v. 18, n. 2, p. 265-267, 1925.

AGUIAR-MENEZES, E. L. Inseticidas botânicos: seus princípios ativos, modo de ação e uso agrícola. Seropédica: Embrapa Agrobiologia, 2005. 58 p.

AMARAL, D. S. L.; VENZON, M.; PALLINI, A. Manejo de pragas na cafeicultura orgânica. In: ZAMBOLIM, L. (Ed.). Produção integrada de café. Viçosa: Suprema, 2003. p. 67-86.

BABU, T. R.; AZAM, K. M. Biology of Cryptolaemus montrouzieri Mulsant (Coccinellidae: Coleoptera) in relation with temperature. Entomophaga, Paris, v. 32, n. 4, p. 381-386, 1987a. 
. Residual toxicity of different insecticides to the adult Cryptolaemus montrouzieri Mulsant (Coccinellidae: Coleoptera). Tropical Pest Management, Basingstoke, v. 33, n. 2, p. 180-181, 1987 b.

BAKKER, F. M.; GROVE, A.; BLÜMEL, S.; CALIS, J.; OOMEN, P. Side-effect test for phytoseiids and their rearing methods. IOBC/WPRS Bulletin, Montfavet, v. 15, n. 3, p. 61-81, 1992.

BANKEN, J. A. O.; STARK, J. D. Multiple routes of pesticide exposure and the risk of pesticides to biological controls a study of neem and the sevenspotted lady beetle (Coleoptera: Coccinellidae). Journal of Economic Entomology, Lanham, v. 91, n. 1, p. 1-6, 1998.

BARTLETT, B. R.; LLOYD, D. C. Mealybugs attacking citrus in California; a survey of their natural enemies and release of new parasites and predators. Journal of Economic Entomology, Lanham, v. 51, n. 1, p. 90-93, 1958.

BELLOWS, T. S.; MORSE, J. G.; HADJIDEMETRIOU, D. G.; IWATA, Y. Residual toxicity of four insecticides used for control of citrus thrips (Thysanoptera: Thripidae) on three beneficial species in a citrus agroecosystem. Journal of Economic Entomology, Lanham, v. 78, n. 3, p. 681-686, 1985.

BERTI FILHO, E.; MENEZES, E. B.; MORAES, G. J. A introdução de Cryptolaemus montrouzieri (Coleoptera: Coccinellidae) para o controle biológico da cochonilha do abacaxi Dysmicoccus sp. In: REUNIÃO ANUAL DA UNIVERSIDADE FEDERAL DE VIÇOSA, 1., 1973, Viçosa, MG. Anais... Viçosa, MG: UFV, 1973. p. 63.

BOYERO, J. R.; RODRÍGUEZ, N.; SURIA, R.; RUÍZ, R.; PASCUAL, F. Efectos de varios plaguicidas sobre Cryptolaemus montrouzieri Mulsant y Rhyzobius lophantae Blaisdell (Coleoptera: Coccinellidae). Boletín de Sanidad Vegetal de Plagas, Madrid, v. 31, n. 1, p.7987, 2005.

BUSOLI, A. C.; BISSOLI, G.; PEREIRA, F. F. Seletividade do extrato pirolenhoso (Biopirol) sobre larvas de joaninha Hippodamia convergens GuerinMeneville, 1824 (Coleoptera: Coccinellidae). In: CONGRESSO BRASILEIRO DE ALGODÃO, 4., 2003, Goiânia. Anais... Goiânia: Embrapa Algodão, 2003. p. $1-4$.

CROFT, B. A. Arthropod biological control agents and pesticides. New York: Wiley, 1990. 723 p.

HASSAN, S. A. Guidelines for testing the effects of pesticides on beneficial organisms: description of test methods. IOBC/WPRS Bulletin, Montfavet, v. 15, n. 3, p. 18-39, 1992.
ISMAN, M. B. Botanical insecticides, deterrents, and repellents in modern agriculture and increasingly regulated world. Annual Review of Entomology, Stanford, v. 51, p. 45-66, 2006.

JACAS, J. A.; VIÑUELA, E. Analysis of a Laboratory method to test the effects of pesticides on adults females of Opius concolor (Hym., Braconidae), a parasitoid of olive fruit fly, Bactrocera olea (Dip., Tephritidae). Biocontrol Science and Technology, Oxford, v. 4, n. 2, p. 147-154, 1994.

MAGANO, D. A.; STORCH, G.; AZEVEDO, R. de; SILVA, F. F. da; BRIZOLA, R. M. de O.; BEZERRA, A. J. A. Sustentabilidade das unidades de produção dos produtores de produtos orgânicos do sul do Rio Grande do Sul. In: ENCONTRO DE PÓS-GRADUAÇÃO, 5.; CONGRESSO DE INICIAÇÃO CIENTÍFICA, 12., 2003. Pelotas, RS. Anais... Pelotas, RS: UFPel, 2003. 1 CD-ROM.

NARDO, E. A. de; TAVARES, M. T.; SA, L. A. N. de; TAMBASCO, F. J. Perspectivas do controle biológico da praga quarentenária cochonilha rosada no Brasil (Maconellicoccus hirsutus (Green) (Hemiptera: Pseudococcidae). Jaguariúna: Embrapa Meio Ambiente, 1999. $38 \mathrm{p}$.

RIGITANO, R. L. O.; CARVALHO, G. A. Toxicologia $e$ seletividade de inseticidas. UFLA: FAEPE, Lavras, $2001.72 \mathrm{p}$.

RIPPER, W. E.; GREENSLADE, R. M.; HARTLEY, G. S. Selective insecticides and biological control. Journal of Economic Entomology, Lanham, v. 44, n. 4, p. 448$458,1951$.

ROCHA, L. C. D. Seletividade fisiológica de inseticidas utilizados em cultura cafeeira sobre os predadores Chrysoperla externa (Hagen, 1861) (Neuroptera: Chrysopidae) e Cryptolaemus montrouzieri Mulsant, 1853 (Coleoptera: Coccinellidae). 2008. Tese (Doutorado em Entomologia) - Universidade Federal de Lavras, Lavras.

ROSSINI, A.; DE BORTOLI, S. A.; AMORIM, L. C. S.; GRAVENA, S. Efeito do óleo de neem (Azadirachta indica) sobre adultos de Cryptolaemus montrouzieri Mulsant (Coleoptera: Coccinellidae). In: SIMPÓSIO DE CONTROLE BIOLÓGICO, 8., 2003, São Pedro, SP. Resumos... Piracicaba: SEB, 2003. p. 170.

SANCHES, N. F.; SILVA, E. S.; CARVALHO, R. S. Biological aspects of exotic predator Cryptolaemus montrouzieri (Coleoptera: Coccinellidae), reared on Planococcus citri in laboratory. In: INTERNATIONAL CONGRESS OF ENTOMOLOGY, 21., 2000, Foz do Iguaçu. Abstracts... Londrina: Embrapa Soja, 2000. p. 
415.

SILVA, F. A. DA; MARTINEZ, S. S. Efeito de soluções aquosas de óleo de sementes de nim, Azadirachta indica, na sobrevivência e desenvolvimento do predador Cycloneda sanguinea (L.) (Coleoptera: Coccinellidae). Neotropical Entomology, Londrina, v. 33, n. 6, p. 751757, 2004.

SIMMONDS, M. S. J.; MANLOVE, J. D.; BLANEY, W. M.; KHAMBAY, B. P. S. Effect of botanical insecticides on the foraging and feeding behavior of the coccinellid predator Cryptolaemus montrouzieri. Phytoparasitica, Bet Dagan, v. 28, n. 2, p. 99-107, 2000.

SMITH, S. F.; KRISCHIK, V. A. Effects of biorational pesticides on four coccinellid species (Coleoptera: Coccinellidae) having potential as biological control agents in interiorscapes. Journal of Economic Entomology, Lanham, v. 93, n. 3, p. 732-736, 2000.

TEDESCHI, R.; ALMA, A.; TAVELLA, L. Side-effects of three neem (Azadirachta indica A. Juss) products on the predator Macrolophus caliginosus Wagner (Het., Miridae). Journal of Applied Entomology, Berlim, v. 125, n. 7/8, p. 397-402, 2001.

ULRICHS, C. H.; MEWIS, I.; SCHNITZLER, W. H. Efficacy of neem and diatomaceous earth against cowpea aphids and their deleterious effect on predating Coccinellidae. Journal of Applied Entomology, Berlim, v. 125, n. 9-10, p. 571-575, 2001.

VENZON, M.; ROSADO, M. C.; PINTO, C. M.; DUARTE, V. S.; EUZÉBIO, D. E.; PALlinI, A. Potencial de defensivos alternativos para o controle do ácaro-branco em pimenta "Malagueta". Horticultura Brasileira, Brasília, v. 24, n. 2, p. 224-227, 2006. 
Efrom, C. F. S. et. al. 